\title{
The Internet and Copyright Protection: Are We Producing a Global Generation of Copyright Criminals
}

Fredrick Oduol Oduor

Follow this and additional works at: https://digitalcommons.law.villanova.edu/mslj

Part of the Entertainment, Arts, and Sports Law Commons, and the Intellectual Property Law Commons

\section{Recommended Citation}

Fredrick O. Oduor, The Internet and Copyright Protection: Are We Producing a Global Generation of Copyright Criminals, 18 Jeffrey S. Moorad Sports L.J. 501 (2011).

Available at: https://digitalcommons.law.villanova.edu/mslj/vol18/iss2/6

This Article is brought to you for free and open access by Villanova University Charles Widger School of Law Digital Repository. It has been accepted for inclusion in Jeffrey S. Moorad Sports Law Journal by an authorized editor of Villanova University Charles Widger School of Law Digital Repository. 


\title{
THE INTERNET AND COPYRIGHT PROTECTION: ARE WE PRODUCING A GLOBAL GENERATION OF COPYRIGHT CRIMINALS?
}

\author{
Fredrick OduOl OduOR*
}

\begin{abstract}
The advent of the Internet poses fundamental changes in social norms, politics and economics in society. The belief in cyber anarchy; "do not touch the Internet" mantra, has fundamentally altered the understanding of copyright laws amongst the present generation. Subsequently an aversion for property rights, as understood by well established copyright laws has, developed manifesting itself mainly through piracy. The evolution of technology in tandem with the Internet has further exacerbated the situation as a whole, generations that enjoy entertainment find it much easier to infringe on a litany of copyright laws. Taking into account the established norms of property or copyright protection, is it not clear, with growing copyright malcontents and malfeasance, that we are simply producing a global generation of copyright criminals. This discourse explores the veracity of this statement by taking into account the nature of the Intermet, the emergence of digital copying and sharing, alongside the fluid perceptions of copyright protection.
\end{abstract}

\section{INTRODUCTION}

A man once told me, a man well-versed [in computer crimes]: 'You know, my 13-Year-old daughter knows that she can't open other people's physical mail and read it. She doesn't go into her sister's bedroom when the door is closed. She doesn't know how to act online. She doesn't know what to do with other people's email.' 1

* Fredrick Oduol Oduor is a recent graduate of the Master of Laws program at Deakin University (with High Distinction) in Australia. Prior to receiving his Master of Laws, Oduor received a Post Graduate Diploma in Legal Practice from Kenya School of Law and a Bachelor of Laws (with Honors) from Moi University in Kenya. He is currently a candidate with the Chartered Institute of Arbitrators, an Advocate of the High Court of Kenya with Omondi Waweru \& Company Advocates, and a Business Law Lecturer at Moi University and Mombasa Polytechnic University College respectively. I would like to thank my family and friends who have always believed in me and Professor Mirko Bagaric and Louis De Koker for their unwavering support.

1. Albert Kovacs, Quieting the Virtual Prison Riot: Why the Internets Spirit of "Sharing" must be Broken, 51 DuKe L.J. 753, 758 (2002) (quoting Janet Reno, Statement at the Symposium of the Americas: Protecting Intellectual Property in the Digital Age (Sept. 12, 2000), available at http://www.cybercrime.gov/ipsymposium.htm (last visited Mar. 23, 2011)). 
Th [e] unrestricted flow of information results in a mutation and misunderstanding of property rights and has seduced a generation into equating stealing with 'sharing.' ${ }^{2}$

The Internet has changed several perceptions about the world today including the way people shop, communicate and even conduct personal and business affairs such as buying airline tickets and obtaining driving directions. Consequently, the Internet also distanced people from the rules and moral conceptions that bind people in the "real world." 3 Perceptions on crime in the ambivalent virtual world-physical world dichotomy are skewed because the virtual world has the effect of physical "depersonalization," also offering dual citizenship (netizen) to the anonymous user, which eventually creates conflict for the individual committing the crime on the Internet. ${ }^{4}$

The idea of copyright protection has not been left out in the development of this online moral quandary. An entire younger generation perceives copyright protection very differently from their parents and forefathers. ${ }^{5}$ This Comment first provides an overview of the background of Internet and copyright protection. ${ }^{6}$ It then summarizes the problem of a generation of copyright criminals. ${ }^{7}$ Lastly, it analyzes morality and punishment, taking into consideration shifting norms and perceptions. ${ }^{8}$

2. Id. at 761 .

3. See id. at 753 (questioning whether Internet could distance people from real world).

4. See Orin S. Kerr, Virtual Crime, Virtual Deterrence: A Skeptical View of Self-Help, Architecture, and Civil Liability, 1 J.L. EcoN. \& PoL'y 197, 199 (2005) (discussing misguided views of Internet world). See also Kovacs, supra note 1, at 758 (stating that moral confusion is partly caused by "physical 'depersonalization' of the Internet," and "moral dilemma that results from the libertarian structure of much of the Internet stems from what can be seen as the dual citizenship of the 'netizen.'").

5. For a discussion regarding young people's perception of copyright protection, see infra notes 40-67 and accompanying text.

6. For a discussion regarding the background of Internet and copyright protection, see infra notes 7-36 and accompanying text.

7. For a discussion regarding the past generation of copyright criminals, see infra notes 39-105 and accompanying text.

8. For a discussion regarding the morality and punishment of these crimes, see infra notes 106-148 and accompanying text. 


\section{Historical and Current Underpinnings of the InTERnet and Copyright Protection}

The Internet was conceptualised out of the desire to develop a system of communication that could withstand a nuclear war. ${ }^{9}$ The architecture of the Internet therefore ensures that communication is not dependent on a single path of information flow or central server. ${ }^{10}$ It is, however, dependent on a "distributed" architecture that can evade system failures or blockages." John Gilmore, founder of the Electronic Frontier Foundation, noted that the Internet basically interprets censorship as damage and routes around this censorship, which is not surprising considering the logic behind its conceptualization. ${ }^{12}$

These qualities of the Internet are no longer unbeknown to its users, particularly the younger generation that has grown up with access to the Internet and its twin sibling, the computer. ${ }^{13}$ The ability to circumvent data flow has created and reinforced the belief in cyber anarchy. ${ }^{14}$ This essentially involves the elimination of the possibility of censorship, centralized authoritarian monitoring, control or supervision. ${ }^{15}$ These perceptions have placed the Internet on a collision course with established laws, in particular copyright law. ${ }^{16}$

Copyright law, and therefore by extension copyright protection, was conceptualised centuries before the advent of digital era

9. See Kovacs, supra note 1, at 755 ("Internet was designed as a communication that could survive a nuclear war ....").

10. See id. ("[C]ommunication on the network depends not on any single path of information flow or central server ....").

11. See id. (stating that network does not depend on single path of information, "but on a 'distributed' architecture that can circumvent system failures or blockages.").

12. See James Boyle, Foucault in Cyberspace: Surveillance, Sovereignty, and Hardwired Censors, 66 U. CIN. L. REv. 177, 179 (1997) (interpreting quote by John Gilmore which states, "The Net interprets censorship as damage and routes around it.").

13. For a discussion regarding young people's perception of copyright protection, see infra notes 42-69 and accompanying text.

14. For a discussion regarding cyber anarchy, see infra notes $46-51$ and accompanying text.

15. See Kovacs, supra note 1, at 756 ("Internet's capacity to circumvent obstacles to data flow has created a new means of communication that seems to eliminate the possibility of censorship or centralized authoritarian monitoring, control, or supervision.").

16. For a discussion regarding the morality and punishment of these crimes, see infra notes 72-82 and accompanying text. 
technologies such as computers and the Internet. ${ }^{17}$ Copyright can be traced back to the fifteenth century in the years subsequent to the invention of the printing press. ${ }^{18}$ Copyright was initially a monopoly over the printing of books granted by the monarch to members of the Stationers' Company. ${ }^{19}$ Not until the Statute of Anne in 1709, which was an "Act for Encouragement of Learning and for Securing the Property to Copies of Books to Rightful Owners Thereof," that rights of authors to their works were recognized. ${ }^{20}$ This ushered in, albeit in its nascent form, property rights in copyright as envisioned today. ${ }^{21}$

Over the past few centuries, the scope and parameters of copyright have expanded to meet society's needs. ${ }^{22}$ The incremental increase of the scope of copyright now includes new forms of creative material and new ways of distributing those materials, which have been made possible by technological advances. ${ }^{23}$ As the Statute of Anne marks its 300th anniversary, Fitzgerald has noted that "there is no doubt that concepts about how to manage, control and share knowledge, culture and creativity existed in societies well before $1709 / 10$ but it is the Statute of Anne that is the symbolic birthplace of what we know as modern copyright law." 24

\section{A. Legal Structures of Copyright Protection}

Currently, there are several laws that inform and govern copyright protection. In utilising a top-down approach in enumerating these structures, it is imperative to begin by acknowledging the existing international legal structures. One of the earliest international agreements in place regarding copyright law dates back to 1886, this is the Berne Convention for the Protection of Literary

17. See Brian Fitzgerald et al., Internet and E-Commerce law: TechnolOGY LAW AND POLICY 154 (Lawbook Co.) (2007) (discussing early copyright problems).

18. See id. (stating that invention of printing press in late 15 th century had greatest impact in emergence of copyright law).

19. See David Bainbridge, Intellectual Property 28 (Pitman Publishing) (1996) ("By an Act of 1529, Henry VIII set up a system of privileges and printing came to be controlled by the Stationers' Company, originally a craft guild.").

20. See Fitzgerald, supra note 17, at 154 (noting that Statute of Anne 1709 paved way for recognition of authors' rights).

21. See id. (reflecting on property rights created through copyright).

22. See id. (noting expansion of copyright law).

23. See id. (discussing evolution of copyright over years to accommodate society's needs for changes in technology).

24. Brian Fitzgerald, Copyright 2010: The Future of Copyright, EuROPEAN INTELL. Prop. Rev. (2008), available at http://eprints.qut.edu.au/13305/1/13305.pdf (last visited Mar. 23, 2011). 
and Artistic Property (Berne Convention). ${ }^{25}$ The Agreement on Trade-Related Aspects of Intellectual property Rights (TRIPS) currently stands-out at the international level after the US successfully lobbied for its inclusion in the Uruguay round of trade negotiations. ${ }^{26}$ Taking into account the establishment of the World Trade Organization (WTO) and the "Single Undertaking Approach" used in its establishment, the TRIPS agreement received the necessary trigger effect to gain ratification in tandem with the WTO. Several countries are party to this multilateral treaty, which sets up minimum intellectual property benchmarks required from members. ${ }^{27}$ The World Intellectual Property Organization (WIPO) continues to coordinate the negotiation of the WIPO Copyright Treaty (WCT) and the WIPO Performers and Phonograms Treaty (WPP), which aims to update the international copyright law framework to meet digital era requirements. ${ }^{28}$

Domestically and regionally, certain other laws are worth noting. Preferential Trade Agreements, such as the Australia-United States Free Trade Agreement (AUSFTA) and the European Commission's Directive for the Enforcement of Intellectual Property Rights, also regulate copyright. ${ }^{29}$ In Australia, the Copyright Act of 1968 governs the most recent amendments reflected in the Copyright Amendment Act of 2006. Perhaps more important is United States domestic copyright legislation, in particular the Digital Mil-

25. See Dr. Lulin Gao, Intellectual Property Rights in the Internet Era: The New Frontier, 5 J. Marshall Rev. InTell. Prop. L. 589, 589 (2006) (noting year Berne Convention was concluded).

26. See J. Carlos Fernandez-Molina \& J. Augusto Chaves Guimaraes, The WIPO Development Agenda and the Contribution of the International Library Community, 27 ELECTRONIC LIBR. 1010, 1014 (discussing pressure exerted by US to ensure that developing countries acquiesced to TRIPS Agreement).

27. See Christoph Schewe, The WTO and Recent Developments in the World, 3 Acta Societatis MarTensis 188, 190 (2008) ("During the negotiations, the participating states adhered to the so-called 'single undertaking approach' which left it to the aspirants to sign all of the WTO agreements or refrain from doing so. In the end, 125 members signed the 'Final Act' on 15 April 1994 in Marrakesh.").

28. See William Cornish \& David Llewelyn, Intellectual Property: Patents, Copyright, Trade Marks and Allied Rights 399 (Sweet \& Maxwell Limited 2007) (1937) ("In the end the two treaties made only cautious changes to the international law which will affect copyright on the internet. That is a desirable outcome, given that technology is still so novel and its possibilities are constantly expanding.").

29. See United States-Australia Free Trade Agreement, U.S.-Austl., art. 17.11(27), May 18, 2004, 43 I.L.M. 1248, available at http://www.ustr.gov/sites/ default/files/uploads/agreements/fta/australia/asset_upload_file469_5141.pdf (last visited Mar. 23, 2011) [hereinafter AUSFTA] (providing directive 2004/48/ EC on enforcement of intellectual property rights). 
lennium Copyright Act ("DMCA") of 1998. ${ }^{30}$ The logic behind this assertion is two pronged. First, the DMCA continues to serve and has "served" as a prototype for international agreements and particular countries' domestic legislation. ${ }^{31}$ The United States, for example, "strong-armed Chile and Singapore to adopt controversial provisions of the DMCA in their free trade agreements." ${ }^{32}$ The second reason for this assertion is the DMCA's extraterritorial effect, resulting from the United States' Internet dominance, which also places in perspective the Internet's borderless nature. ${ }^{33}$

\section{B. Principles and Anchors of Copyright Protection}

In addition to the copyright protections found in the laws already mentioned, there are, in addition, various principles or anchors that have been developed over the years upon which copyright protection operates. These are rooted in the purpose of intellectual property law which is to encourage creativity, originality, invention, and security of ownership. ${ }^{34}$ Copyright law protects the manner or form in which ideas are expressed, not the ideas themselves; this is often referred to as the idea-expression dichotomy. ${ }^{35}$ Accordingly, copyright law provides only limited rights to original expression of ideas so as not to overly restrict public access and use of new work during the term of the copyright. ${ }^{36}$

Additional notable copyright principles, including fair use privilege, the first use doctrine, and several other statutory exemptions allow for limited sharing of copyrighted works. ${ }^{37}$ These principles

30. See generally CORNISH \& LLEWELYN, supra note 28 (discussing DMCA birth and evolution).

31. See id. at 680 ("The Digital Millennium Copyright Act of 1998 introduced in the United States and has been followed by the EC's Directive on Information Society Copyright...."). (2005).

32. Peter Yu, P2P and the Future of Private Copying, 76 U. Colo. L. Rev. 653, 690

33. See id. (discussing United States' ability to push other countries to take particular position on copyright law).

34. See Robert Kasunic, Preserving the Traditional Contours of Copyright, 30 Colum. J.L. \& ARTs 397, 401 (2007) ("By precluding the control of ideas, the idea/ expression dichotomy encourages a multiplicity of expressions about an idea in a manner that fosters the advancement of knowledge.").

35. See id. (defining idea and expressing dichotomy).

36. See Geraldine Moohr, The Crime of Copyright Infringement: An Inquiry Based on Morality, Harm, and Criminal Theory, 83 B.U. L. Rev. 731, 746 (2003) ("[C]opyright law provides only limited rights to original expression of ideas, so as not to overly restrict public access and use of new work during the term of the copyright. $\left.{ }^{n}\right)$.

37. See Yu, supra note 32 , at 667 ("Copyright law is 'notoriously complex and subtle.' It includes many 'muddy rules,' such as the idea-expression dichotomy, 
often differ from jurisdiction to jurisdiction despite the conspicuous tilt towards the U.S. approach. ${ }^{38}$ Copyright law is rather complex, and principles, such as the idea-expression dichotomy that attempt to anchor copyright law, have always remained rather elusive. ${ }^{39}$

\section{An Overview of a Generation of Criminals}

An entire generation of copyright criminals seem to be loose on the Internet. This is partially attributable to shifting cultural norms relating to copyright law. ${ }^{40}$ This shift is exacerbated by technological advancement. ${ }^{41}$ The growth of the culture of sharing particularly in the form of peer to peer (P2P) file sharing on the Internet - has greatly challenged copyright laws. ${ }^{42}$ Copying, digital rights management, and remixing are other trends that have challenged copyright laws; yet, they have gained a strong foothold amongst the younger generation. ${ }^{43}$ Concurrently, copyright laws have evolved over time, now encompassing severe criminal penalties for infringement in the digital era. ${ }^{44}$ The reasoning behind these developments in copyright law is that a copyright is property and knowingly taking property without permission is a crime, just like shoplifting. ${ }^{45}$

Infringement by competitors for commercial purposes has been a crime in the United States since 1897, but it was initially

the fair use privilege, the first sale doctrine, and various statutory exemptions that allow for limited sharing of copyrighted works.").

38. See id. at 687-89 (highlighting various arrangements between U.S. and other countries "to facilitate the gradual inclusion of trading partners into the global economy").

39. See id. at 667 (noting copyright laws are complex and contain many subtleties).

40. See Jessica Litman, Sharing and Stealing, 27 Hastings Comm. \& ENT. L.J. 1, 20-21 (2005) (noting service of over one thousand subpoenas on internet sites and colleges by record industry regarding possession of unauthorized digital copies).

41. See id. at 9 (acknowledging "astonishing" rate of adoption of Internet as premiere research tool).

42. See id. at 2-3 ("Legislation pending in Congress seeks to deter consumers from engaging in peer-to-peer file sharing.").

43. See id. at 36 (recognizing difficulties associated with digital rights management formats).

44. See Moohr, supra note 36, at 783 (discussing criminalization of copyright laws and their effects).

45. SeeYu, supra note 32, at 668 (quoting Dowling $v$. United States, 473 U.S. 207, 217-18 (1985) stating that "[w]hile one may colloquially link infringement with some general notion of wrongful appropriation, infringement plainly implicates a more complex set of property interests than does run-of-the-mill theft, conversion, or fraud."). 
categorized as a misdemeanour, not a felony. ${ }^{46}$ Its status as a misdemeanour showed congressional apprehension over making copyright infringement an outright, reprehensible criminal act, placing the infringement in the company of other, tangible property crimes. ${ }^{47}$ New legislation worldwide is increasingly moving towards penal sanctions, which protect all types of copyrighted material, including increased criminal penalties and criminal provisions to protect quasi-copyright material. ${ }^{48}$ The enactment of the Electronic Theft Act by the U.S. Congress, for example, removed the requirement of financial gain and, by extension, the commercial purpose requirement, while the DMCA criminalizes conduct that may lead to infringement. ${ }^{49}$ The DMCA's mass adoption in other territories as a prototype and its unintended extraterritorial effect as previously enunciated, should be kept in mind.

\section{A. A Generation of Criminals or Simply Hyperbole?}

From the onset of the Internet, there is a widening divide between copyright holders and the users of copyright protected works. ${ }^{50}$ The former are simply eager to protect their interests while the latter do not understand their stakes in the copyright system. ${ }^{51}$ Children and teenagers do not fully grapple and appreciate the "economic plight of artists and songwriters." 52 The conduct of an entire generation, with regard to copyright laws, was rarely scrutinised or problematic prior to the advent of the Internet. ${ }^{53}$ Furthermore, this generation's indifference was of little concern to the

46. See Moohr, supra note 36 , at 736 ("Preventing infringement by competitors of those who hold copyrights is a core feature of copyright law . . [and] categorized for eight decades as a misdemeanour, not a felony.").

47. See id. (noting that crime was misdemeanor for eighty years negating perception of "congressional endorsement of a criminal solution to copyright infringement").

48. See id. at 736-37 ("New legislation applied penal sanctions to protect all types of copyrighted material, increased the severity of criminal penalties, and utilized criminal provisions to protect quasi-copyright material.").

49. See id. at 737-38 ("Congress to enact the NET, which eliminated the requirement of financial gain and thus of commercial purpose. . . . [thus removing] the historical division that had protected non-competitive users from criminal liability. . . . [I]n enacting the DMCA, Congress went further by criminalizing conduct that might lead to infringement.").

50. See Yu, supra note 32 , at 756 (discussing divide between internet users and users of copyright protected works).

51. See id. (" $[\mathrm{T}]$ here is a widening divide between copyright holders, who are eager to protect their interest, and the users of copyrighted works, who do not understand their stakes in the copyright system.").

52. Id.

53. See id. at 732 (citing digitalization as increasing availability of music, movies, books and etc. to consumers). 
recording and film industry because their only connection to music and film products was largely in the form of retail purchases and consumption. ${ }^{54}$ Today, however, there is need to fix this attitude which now poses "a problem for copyright holders, as the Internet has given kids ample opportunity to make high-quality reproductions of music" and films..$^{55}$ They are therefore able to acquire and distribute music free of charge for a profit or simply leisure. Children's attitude toward copyright infringement may change once they have grown much older and begin to appreciate the import of not having been paid for a hard day's work. ${ }^{56}$ It is important to remember, for example, parents are the ones buying the computers, but generally the children who buy the CDs used to download the music.

The self styled Robin Hood generation has already begun to find itself in the dock en masse. ${ }^{57}$ The reaction of the music industry in particular the Recording Industry Association of America (RIAA) has become increasingly penal to music piracy. ${ }^{58}$ This was because after the "emergence of Napster and P2P file sharing, . . CD sales plunged by more than six percent in 2001, nearly nine percent in 2002, and slightly more than seven percent in 2003. To stem its losses, the industry has employed [four] different strategies: lobbying, litigation, education, and licensing." 59 Particular focus is paid to litigation and some of its peripheral aspects such as settlements and affidavits of compliance, to show the disregard for copyright laws by an entire generation. ${ }^{60}$ The statistics in question already indicate that disregard for copyright law has become the

54. See id. (noting increased availability through digitalization as making products "more vulnerable to unauthorized use").

55. Id. at 756 .

56. See id. (" $[\mathrm{A}] \mathrm{s}$ they grow older and start working full-time, their perspective on copyright may change. They may empathize with artists and songwriters as they experience the pain of not getting paid for a hard day's work.").

57. See Aaron Delgado, Confession of a Shoe Pirate-Can Proper Pricing of Factors of Production Deter Copyright Infringement, 8 J. TЕсH. L. \& PoL'Y 179, 183 (2003) (" $[\mathrm{P}]$ eer-to-peer software constitutes pirate's sword to some, while to others, Robin Hood's arrow.").

58. See Yu, supra note 32, at 654 (describing RIAA litigation in 2003 as "launch [ing] full-fledged battles against individuals suspected of swapping music without authorization via peer-to-peer ("PRP") networks. . " and resulting in hundreds of filed lawsuits).

59. Id. at 658 .

60. See id. at 776 ("The Napster experience illustrates the ineffectiveness of legal prohibitions in forming social norms ..."). 
norm and most forms of cyber anarchy are increasingly considered to be Internet axioms. ${ }^{61}$

In 2003 major record labels filed high-profile lawsuits against four college students from Michigan Technological University (MTU), Princeton University and Rensselaer Polytechnic Institute. ${ }^{62}$ The labels alleged that the students had infringed upon the companies' copyrights by engaging in $\mathrm{P} 2 \mathrm{P}$ file sharing that helped others on campus share copyrighted songs. ${ }^{63}$ The labels sought the maximum statutory damages afforded by the 1976 Copyright Act of $\$ 150,000$ for each illegal download and also permanent injunctions to shut down the networks. ${ }^{64}$ Luckily for the students, a settlement was reached that ranged from $\$ 12,000$ to $\$ 17,500$, thus marking an important milestone for major labels-"never before had they recovered money from individuals they had accused of online piracy." 65

There have been many casualties of the music industry's decision to tackle piracy through its attack dog, the RIAA, including several cases of mistaken identity. ${ }^{66}$ The RIAA introduced "Web crawlers and other computer programs to scour the Internet for what they believe to be illegally traded songs." 67 This drastically assisted in reducing costs of policing the Internet; however, the RIAA has also yielded false positives. ${ }^{68}$ A good example of a false positive was the confusing of Peter Usher, a retired astrophysics professor at

61. See Kovacs, supra note 1 , at 765 (describing disregard for copyright law becoming norm).

62. SeeYu, supra note 32 , at 659 (discussing high-profile lawsuits filed by major record labels against college students).

63. See id. at 660 (discussing lawsuits against four college students brought by major record labels).

64. See id. (" $[T]$ he record companies not only asked the courts for permanent injunctions to shut down the networks but also sought the maximum statutory damages afforded by the 1976 Copyright Act $-\$ 150,000$ for each illegal download.").

Some commentators applauded the settlement, noting that the damage amounts were 'high enough to catch the attention of file swappers' and intimidate them from continuing their illegal practices. Others, however, predicted that the settlements would backfire on the industry by alienating paying customers who were disgusted by the industry's strong-arm tactics.

Id. at $600-61$.

65. Id.

66. See, e.g., Yu, supra note 32, at 662 (explaining Peter Usher's case of mistaken identity).

67. Id.

68. See id. (stating "although these automated Web crawlers drastically reduced the costs of policing copyrights, they also yielded false positives that caused the industry public embarrassment."). 
Pennsylvania State University, with Usher Raymond, a best-selling rhythm and blues artist. ${ }^{69}$ The crawler located, on the University's departmental server, a directory named "usher" that had a sound file in MP3 format. ${ }^{70}$ This resulted in the RIAA sending Professor Usher a cease-and-desist letter, yet the song in question happened to be an a cappella group of Penn State astrophysicists. ${ }^{71}$ Occurring in mid-2003 amidst the U.S. "piracy wars," the RIAA's letter had a chilling effect: the Department of Astronomy and Astrophysics noted it would shut down the department's Internet connection in forty-eight hours if the "infringing material" was not removed within this timeframe. ${ }^{72}$

In September 2003, amidst the war on piracy, through mass litigation the RIAA filed 261 lawsuits against individuals who downloaded music illegally via P2P networks. ${ }^{73}$ In July, the RIAA had issued 871 federal subpoenas and roughly seventy-five new subpoenas were approved every day. ${ }^{74}$ In September, however, the RIAA offered not to sue those who removed illegal music files and signed affidavits promising not to download music illegally again. ${ }^{75}$ Ironically, this affidavit of amnesty, which essentially also acted as an admission to the intentional commission of crimes, did not shield the individuals from other civil actions and federal criminal prosecution. ${ }^{76}$ These affidavits could also act as a source for creating a blacklist of copyright offenders; however, that idea was chal-

69. See id. (saying "the RIAA's crawlers confused Peter Usher, a retired professor of astronomy and astrophysics at Pennsylvania State University, with Usher Raymond, the best-selling rhythm-and-blues performer.").

70. See id. (discussing false positive occurrence at Pennsylvania State University).

71. See id. (noting specifics of cease-and-desist order sent wrongly to Professor Usher or Pennsylvania State University).

72. See Yu, supra note 32, at 662 (remarking effect of wrongful cease-and-desist letter sent to Professor Usher).

73. See id. at 663 ("In September, the RIAA filed 261 lawsuits against individuals who downloaded music illegally via P2P networks."). The RIAA had the power to launch these mass litigations from a grant of power by the DMCA to subpoena, as well as from the precedent set by the Verizon cases. See id. (noting RIAA's ability to file mass lawsuits.) See also In re Verizon Internet Servs., Inc.,240 F. Supp. 2d 24 (D.D.C.), rev'd Recording Indus. Ass'n of Am. v. Verizon Internet Servs., Inc., 351 F.3d 1229 (D.C. Cir. 2003) \& In re Verizon Internet Servs., Inc., 257 F. Supp. 2d 244 (D.D.C.) rev'd, Recording Indus. Ass'n of Am. v. Verizon Internet Servs., Inc., 351 F.3d 1229 (D.C. Cir. 2003).

74. See Yu, supra note 32, at 662 ("By mid-July, the industry had set out 871 federal subpoenas, and roughly seventy new subpoenas had been approved every day.").

75. See id. at 664 (discussing supposed leniency of RIAA on infringers via amnesty program).

76. See id. ("Even worse from the file-traders' perspective, the participants would have admitted past illegal file-trading activities by signing the affidavits."). 
lenged in court and the RIAA announced the discontinuance of its amnesty program in April 2004. ${ }^{77}$

Clearly, the description of a global generation of copyright criminals is not an overstatement. More importantly, the import of the statement must be realized as this is not just an issue of a generation of copyright criminals, but also an issue of criminalizing of an entire generation on the basis of the current understanding of copyright protection. Ironically, with regard to criminalizing an entire generation, the ambit spreads further than children and teenagers; effectively spreading to the older generation. This is despite the fact that part of the older generation is responsible for being unyielding to a rethink of copyright law. ${ }^{78}$ Parents are seemingly turning themselves and their own children into criminals.

Several other cases brought by the RIAA illustrate this position. One lawsuit, albeit misplaced, was against a seventy-one year old man whose teenage grandchildren downloaded music using P2P networks. ${ }^{79}$ Another lawsuit involved a "twelve year old honors student living in public housing, who paid $\$ 29.99$ for KazaA software and may not have been able to distinguish between KazaA . . . or other legal music subscription services," like Press Play. ${ }^{80}$ Yet again another case, which was subsequently dropped, "accused a sixty-sixyear-old Boston woman of offering hardcore rap songs for download although her computer, as it turned out, could not run the file-swapping software she was alleged to be using." 81

YouTube has been referred to as a giant clearing house for copyright infringement because it is estimated that between thirty and seventy percent of its content consists of unauthorized mate-

77. See id. (discussing major problem with RIAA's amnesty program, concluding with program's eventual discontinuation). "In a document filed to dismiss the lawsuit, the RIAA claimed that 'the program is no longer necessary or appropriate' in light of the fact that public awareness of the illegality of online file trading has increased substantially since the group launched the individual lawsuits and the amnesty program." Id.

78. For a discussion regarding the current copyright laws, see infra notes 106167 and accompanying text.

79. See Yu, supra note 32, at 665 (discussing lawsuit against seventy-one year old man for acts of his grandchildren.); see also Chris Gaither, Group Sues 261 over Music-Sharing, Boston Globe, Sept. 9 2003, at A1.

80. See Yu, supra note 32, at 665 (discussing lawsuit against twelve year old honors student); see also, Tim Arango et al., Music-Thief Kid Sings Song, N.Y. Post, Sept. 10, 2003, at 21. Eventually the student came to a settlement with the RIAA for $\$ 2,000$. See John Borland, RIAA Settles with 12-year-old Girl, CNET News.COM (Sept. 9, 2003), available at http://news.com.com/2100-1027-5073717.html (discussing another lawsuit against young Internet user for file swapping).

81. Yu, supra note 32 , at 665 . 
rial. ${ }^{82}$ These include sound recordings, television and movie clips. ${ }^{83}$ The unique nature of YouTube complicates the whole issue further because users can upload and share video clips across the Internet. ${ }^{84}$ It is not surprising that most of these uploads originate from the younger and possibly more tech-savvy generation. It is therefore not surprising that there are several unauthorized utilities and workarounds enabling YouTube videos to be downloaded and stored offline. ${ }^{85}$ Recently, in February 2007, YouTube "deleted almost 100,000 videos in response to a takedown demand from Viacom, owner of MTV, BET, and other media outlets." 86 Perhaps more importantly, to show the recalcitrant nature of copyright infringement online, Viacom opted to sue YouTube in relation to another 150,000 videos, which had remarkably been viewed 1.5 billion times in late $2007 .{ }^{87}$

In his article, For the Love of Culture: Google, Copyright and our Future, discussing copyright issues in the Internet age, Lawrence Lessig rightly supported the position that it is becoming harder to spend an hour on the Internet without colliding with copyright law. ${ }^{88}$ Spending time online involves perpetually meeting potentially actionable events under copyright law. ${ }^{89}$

In Africa, experts often attribute the staggeringly high levels of music and film piracy to poverty. ${ }^{90}$ Poverty may instigate piracy, but

82. See Kurt Hunt, Copyright and You Tube: Pirates Playground or Fair Use Forum?, 14 Mich. Telecomm. \& Tech. L. Rev. 197, 198 (2008) (discussing YouTube's attributes).

83. See id. (noting type of content contained on YouTube).

84. See id. at 201 (describing method of content sharing on YouTube).

85. See id. at 200-01 ("Although YouTube does not allow viewers to download content, there are several unauthorized utilities and workarounds that allow YouTube to be downloaded and stored offline.").

86. Id. at 200 .

87. See id. (quoting complaint at 3, Viacom Int'l, Inc., v. YouTube, Inc., No 1:07CV02103 (S.D.N.Y. filed March 13, 2007)).

88. See Lawrence Lessig, For the Love of Culture: Google, Copyright and our Future, New Rep., Jan, 26, 2010, at 28, available at http://www.tnr.com/article/the-loveculture ("Most of us can no longer spend even an hour without colliding with the copyright law.").

89. See id. ("Technology, heedless of law, has developed modes that insert multiple acts of reproduction and transmission - potentially actionable events under the copyright status - into commonplace daily transactions.").

90. See Property Rights Key to Fighting IT Piracy, Zimbabwe Standard, Nov. 25, 2007, available at http://zw.thestandard.co.zw/business/17130.html (discussing gravity of media piracy throughout Africa). Kenya, for example, has extremely high rates of music piracy. See Carole Croella, On the Beat-Tapping the Potential of Kenya's Music Industry, WIPO MAG., July 2007, available at http://www.wipo.int/ wipo_magazine/en/2007/04/article_0001.html ("The modern musical landscape of Kenya is one of the most diverse and vibrant of all African countries. But underinvestment, ineffective management of intellectual property rights, and rampant 
it is the vice-like nature of piracy, not poverty itself, that perpetuates such activity. ${ }^{91}$ Once piracy becomes the norm, even IT experts succumb to the vice, including those in countries like Kenya and South Africa, where there are clear copyright laws. ${ }^{92}$ In most developing countries, it goes without saying that there are more 'copyright criminals' than in developed countries. ${ }^{93}$ Thus, artists in some of these jurisdictions would prefer even harsher penal laws to increased civil liability. ${ }^{94}$

Developing countries in particular have been wary of intellectual property rights because of their insidious effects. ${ }^{95}$ In his book on free trade and preferential agreements in the trading system, Professor Bhagwatti noted, with regard to preferential trade agreements (PTA) that raise the benchmark set out in TRIPS, that beyond acting as value-based demands, they serve little or no purpose in developing countries. ${ }^{96}$ Thus, as it becomes more difficult to operate in western countries, copyright infringers will set up base in developing countries that have more relaxed copyright laws. ${ }^{97}$ The dawn of international lawsuits targeting file sharers in developed

piracy have prevented the industry from realizing its economic potential and left its artists struggling to earn a living.").

91. See Alfred Hermida, Software Piracy 'Seen as Normal,' BBC News Website (June 23, 2005, 9:56 GMT), http://news.bbc.co.uk/2/hi/technology/4122624.stm (reporting that campaigns to eradicate piracy are ineffective because despite educative measures, people do not see piracy as socially problematic).

92. See Property Rights Key to Fighting IT Piracy, supra note 90 (discussing abundance of copyright infringement in countries with copyright laws with infringement task forces in Kenya, South Africa).

93. See Business Software Alliance, Fifth Annual BSA and IDC Global SOFTWARE PIRACY STUdY 4 (2007), available at http://portal.bsa.org/idcglobalstudy 2007/studies/2007_global_piracy_study.pdf (ranking countries by piracy rates).

94. See Raymond Gichukip, Industry Under Siege By Pirates, Daily Nation, (Nov. 1, 2008), http://www.nation.co.ke/Features/lifestyle/-/1214/486074/-/view/ printVersion $/-/$ mswgsdz/-/index.html (discussing weak penalties for copyright violation and artists' desire for more serious punishment of violators).

95. See A Call to Improve Intellectual Property Rights of Developing Countries, ScIENCE IN AFRICA (Oct. 2010), http://www.scienceinafrica.co.za/2002/october/ip. $\mathrm{htm}$ (noting that enforcing intellectual property rights is not always in best interest of developing countries).

96. See Jagdish Bhagwati, Termites in the Trading System: How preferential Agreements Undermine Free Trade 73 (2008) ("Having managed to get TRIPS inserted thus into the WTO, in violation of the fact that royalty collection is not a trade issue, the IPP lobby proceeded to use PTAs to advance their agendas beyond what the multilateral negotiations had yielded.").

97. See Yu, supra note 32 , at 658 (illustrating instance where copyright infringers, like KazaA, set up base in developing countries with more relaxed copyright laws). The company strategically incorporated itself in Vanuatu, a notorious tax haven for shell companies and financial criminals. See id. (describing KazaA's place of incorporation). KazaA placed its headquarters, however, in Australia, whose parent company - Sharman Networks - was in the United States. See id. (noting location of KazaA's headquarters). 
countries, will push piracy into the developing world even faster. ${ }^{98}$ The thrust to protect copyrighted works is quickly becoming "as concentrated an international event as the war on terrorism." 99

\section{B. The Corridors of Justice and a Generation of Criminals}

At the beginning of the new millennium, online criminals fundamentally changed how they broke copyright laws. ${ }^{100}$ Originally, they used centralized servers to support file sharing. ${ }^{101}$ Napster. com, a student-created program made to facilitate music exchange, pioneered the MP3 and P2P-file sharing technology system that followed this model. ${ }^{102}$ Napster's centralized server, however, made it an easy target for litigation, and despite many attempts to remain viable, the recording industry eventually pushed Napster under. ${ }^{103}$ As a result, subsequent $\mathrm{P} 2 \mathrm{P}$ file-sharing programs created a new model, the client-server model, making it harder to pin liability on a single player by not relying on a centralized server or host. ${ }^{104}$

KazaA's parent company, Sharman Networks, presented an argument to the United States courts that "it did not have substantial contacts with California and thus should not be subject to the court's jurisdiction." See id. Nevertheless, this argument was rejected by the court, which observed that it "could hardly be doubted that a company whose software had been downloaded more than 143 million times by California residents had 'knowingly and purposefully availed itself of the privilege of doing business in California' and had established the requirement minimum contacts with California residents." Id. at 659.

98. See id. at 686 ("In March 2004, the International Federation of the Phonographic Industry unleashed its first wave of international lawsuits, against file-sharers in Canada, Denmark, Germany, and Italy."). In March 2004, the International Federation of the Phonographic Industry began its first wave of international lawsuits targeting file sharers in Canada, Denmark, Germany and Italy. See id. (discussing international lawsuits targeting file sharers).

99. Id. at 694 (quoting producer of latest Star Wars trilogy, Rick McCallum).

100. See Aaron M. Bailey, Comment, A Nation of Felons?: Napster, the NET Act and the Criminal Prosecution of File-Sharing, 50 AM. U. L. REv. 473, 475 (2001) ("At the same time, the Internet is also changing the way laws are broken.").

101. See Delgado, supra note 57, at 181-82 (explaining downfall of early filesharing services).

102. See id. at 180-81 (giving Napster's historical background).

103. See id. at 181 (surveying Napster's litigation history along with attempts to work out agreement with recording industry).

104. See id. at 182.

[S] uccessive software programs that vied for the now vacant throne ... went to a client-server model that did not rely upon a central server or host sites. Instead, these new programs provided what is known as peerto-peer service; there was no central computer server or centralized software of the sort that would give rise to contributory infringement claims.

Id. 
The decision in Metro-Goldwyn-Mayer Studios, Inc. $v$ Grokster $L t d .{ }^{105}$ however, seems to have eased the tidal wave threatening to eradicate P2P networks altogether after Napster. The Court in this case found substantial non-infringing uses for the defendant's software. ${ }^{106}$ Grokster illustrates how technological developments utilized by an entire generation, in particular the younger generation, have a close proximity to committing a criminal offense.

\section{The Internet, Morality and Punishment: ShifTing Cultural Norms}

\section{A. Copyright Moral Theory Reconceptualised}

Considering the level of copyright breach, copyright protection has begun to turn a generation into criminals-albeit the generation in question does not perceive this problem as theft. ${ }^{107}$ Morality plays a fundamental role in the important decisions we make. ${ }^{108}$ Morality consists of principles that determine how serious conflict should be resolved in our lives and society. ${ }^{109}$ Moral philosophy can be divided into non-consequentialist theories (rightsbased theories) and consequentialist moral theories (utilitarianism). ${ }^{110}$ In short, rights-based theories contend that the appropriateness of an action is not contingent upon its instrumental ability to produce particular ends, but follows from the intrinsic features of the act.111 The extent to which conduct conforms to predetermined rules is a dominant feature of rights based theories. ${ }^{112}$ Utilitarianism propounds that morally right actions are those that

105. 259 F. Supp. 2d 1029 (C.D. Cal. 2003) [Grokster], 259 F. Supp. 2d 1029 (C.D. Cal. 2003), Grokster rev'd, 380 F 3d 1154 (9th Cir. 2004), vacated and remanded, 545 U.S. 913 (2005).

106. See Yu, supra note 32, at 671 (quoting Grokster, 259 F. Supp. 2d at 1035).

107. See Diane Zimmerman, Living Without Copyright in a Digital World, 70 ALB. L. REv. 1375, 1376 (2005) (discussing perception of users that "it is not theft to multiply copies without consent in order to space and time-shift access to legitimately obtained music or video, or to share a copy with a friend.").

108. See Mirko Bagaric, So Which Rights are real? 4 Original L. Rev. 78, 82 (2008) ("At its most basic level, morality consists of the principles which dictate how serious conflict should be resolved.").

109. See Mirko Bagaric, How to Live: Being Happy and Dealing with Moral Dilemmas (2006) (discussing various moral principles that can be used to resolve serious conflict in everyday life).

110. See Bagaric, supra note 108 (noting two different groups of moral theories classified by scholars).

111. See id. ("On the basis of such theories, consequences are either an irrelevant or subsidiary consideration in evaluating the morality of an act.").

112. See id. ("Where human rights are regarded as the lynchpin of morality, an action will be judged to be right or wrong depending on the extent to which it observes and accords with predetermined rights."). 
produce the greatest amount of happiness or pleasure and the least amount of pain. ${ }^{113}$ In copyright law, "moral rights" are personal rights belonging to authors or creators of copyright material. Furthermore, copyright law is centered on the relationship between right of attribution and the right of integrity. ${ }^{114}$

For decades, copyright law was deemed to be of utilitarian conception. ${ }^{115}$ This belief exists because copyright law serves to benefit the public by promoting learning and ideas. ${ }^{116}$ Copyright law, therefore, protects authors' interests as a means to an end and protection is not an end in itself. ${ }^{117}$ Accordingly, the natural rights envisioned in "moral rights" conflicts with utilitarianism because "moral rights" do not definitively limit authors' rights. ${ }^{118}$ This explains the current predicament society finds itself in regarding these "moral rights," which are rights-based theories that tend to individualize rights. ${ }^{119}$ Nevertheless, with the advent of the internet, (taking into account copyright's nexus to criminality) a reconsideration of this position is overdue because it has become clear that several alternatives such as creative commons, licensed P2P file-sharing, compulsory licensing, voluntary collective licensing, and technological protection are being considered. ${ }^{120}$

A reconsideration of traditional copyright concepts in relation to the internet is also overdue because conceptualization is apparently inadequate. ${ }^{121}$ Conceptualization creates criminals in mass,

113. See Bagaric, supra note 108 ("According to this theory, each person's interest counts equally and we should act in a manner which maximises net human well-being.").

114. See Fitzgerald, supra note 18 , at 175 (discussing exclusive rights and ownership attached to copyrights).

115. See Moohr, supra note 36, at 745 ("As an instrumental, utilitarian conception, copyright law protects authors' interests ...").

116. See id. at 744 ("The Copyright Clause [of the United States Constitution] states that copyright law exists to benefit the public by promoting learning and ideas.").

117. See id. at 745 ("[C]opyright law protects author's interest as a means to an end; protection is not an end in and of itself.").

118. See id. at 746 ("[T]he idea that authors have a natural claim on their creative expression is a strong undercurrent in copyright discourse. In this view, authors' rights emanate from the Lockean principle that people own the fruits of their labor; it is independent of the utilitarian exchange.").

119. See id. (contending such theory would, if followed through completely, provide authors with unlimited rights in regards to their works).

120. See Zimmerman, supra note 107, at 1376 (describing issues raised by internet age).

121. See id. (explaining that " $\mathrm{t}]$ he essence of traditional copyright is that it lodges with owners the right to control copying .... . [The] logic [of traditional copyright law], however, is entirely out of synch with the way users think about their own rights to use and disseminate digital works.") (footnote omitted). 
specifically the younger generation, and cuts across the board from wealthy to the poor and young to the old. ${ }^{122}$ Happiness cannot be maximized in a society of this nature. A contemporary application of utilitarian calculus shows that a modification of copyright theory is likely to yield more happiness. ${ }^{123}$ There is likely to be a greater amount of happiness with such reconsideration. ${ }^{124}$ Such a change would ensure that copyright law continues to function in society without turning a whole generation into criminals. ${ }^{125}$ Perhaps to illustrate further the impact on society, it would be prudent to consider the comments made by a defendant's father, who owns thousands of records and CDs:

[The RIAA] has sued one of their most avid customers. The RIAA says that they wanted to teach these kids and their families a lesson. The lesson we learned is that we will never, ever buy another product from any of those companies again. That's the lesson we're going to tell everyone. ${ }^{126}$

\section{B. Shifting Norms in Copyright and Punishment}

Documentaries are an example of a great source of culture, but these compilations of creativity are burdened by impossibly complex copyright claims. ${ }^{127}$ Access to knowledge is seemingly

122. See id. (discussing how internet users do not consider downloading and sharing music to be illegal). This phenomenon leads to more people actually stealing music and videos by acquiring them for free on internet. See id. (explaining that misunderstanding copyright laws leads to more copying).

123. See id. at 1384 (saying "[c]onsumers are unwilling to accept the stringent limits on their behavior or the invasions of their privacy that comprehensive DRMs impose."). As a result of this refusal, consumers "are unhappy about paying for content that is governed by them." Id.(citation omitted).

124. See id. (citing Sony DRM as example of unhappiness caused by protecting information with utmost stringency and urging implementation of new business model that accommodates new way that people transmit information over internet).

125. See Elizabeth Townsend Gard, Conversations with Renowned Professors on the Future of Copyright, 12 Tul. J. Tech. \& INTEll. Prop. 35, 36, 38 (2009) (summarizing Professor Zimmerman's position that copyright laws cannot function with internet and that there is "move toward realism" where copyright laws will adapt to ways people interact using internet); Zimmerman, supra note 107, at 1395 (explaining that lawmakers should cautiously amend copyright laws in ways allowing for best business models to remain viable in internet age).

126. Yu, supra note 32, at 680 (footnote omitted).

127. See Lessig, supra note 88 , at 24 ("Documentaries in particular are property of a special kind. The copyright and contract claims that burden these compilations of creativity are impossibly complex."). 
under threat, even as a generation attempts to gain access to it. ${ }^{128}$ In his article, Lessig discusses requirement to seek permission to quote documentaries which is an oddity, particularly because one does not need an author's permission to quote from the New York Times. ${ }^{129}$ YouTube faces some of these problems. ${ }^{130}$ Furthermore, copyright laws can have a chilling effect on information use, as was noted in the case of Professor Usher. ${ }^{131}$ It would be unfortunate if students' attempts to access knowledge turned them into criminals. ${ }^{132}$

The major lawsuits filed against Google in 2005 did not raise any novel issues from those addressed in Grokster because they both revolved around public access to a powerful and comprehensive source of knowledge. ${ }^{133}$ Google planned to create digital copies of nearly eighteen million books with the intention of making them internet accessible. ${ }^{134}$ The American Association of University Presses and the Authors Guild each filed actions against Google, claiming that Google's plan violated copyright laws. ${ }^{135}$ In these cases, Google was clearly disadvantaged because its plan resulted in the centralization, and accordingly greater accessibility, of creative content storage. ${ }^{136}$ If litigated, the centralization of creative con-

128. See id. (describing current situation with documentaries as example of difficulties to attain information). Lessig also noted, "the vast majority of documentaries from the twentieth century cannot legally be restored or redistributed," due to copyright laws. Id.

129. See id. at 25 (remarking on particularity of requiring filmmakers to get permission to quote).

130. See Hunt, supra note 82 , at 198 (noting estimation that thirty percent to seventy percent of material on YouTube infringes on copyrighted material); Whose Video Is It, Anyway? YouTube's Runaway Success Has Opened a Pandora's Box of Copyright Issues, BusINEssWEEK, Aug. 7, 2006, available at http://www.businessweek. com/magazine/content/06_32/b3996051.htm (noting difficulties facing YouTube over copyright laws).

131. See Yu, supra note 32, at 662 (retelling story of Professor Usher receiving cease and desist order from RIAA because they mistakenly believed he shared music from artist Usher with others).

132. See id. (asserting information transmitted by Professor Usher was of school musical group).

133. See Steven Hetcher, The Half-Fairness of Google's Plan to Make the Worlds Collection of Books Searchable, 13 Mich. Telecomm. \& Tech. L. Rev. 1, 3 (2007) (discussing hopes that Supreme Court decision in Grokster would help to clarify copyright issues in cyberspace - also at issue in lawsuits against Google).

134. See id. (expressing Google's intentions).

135. See id. at 4 (describing Google's actions giving rise to lawsuits).

136. See id. ("The alternative between centralization and decentralization of creative content storage determines the central copyright dispute - indirect or secondary liability when the defendant is not a database builder and thus not a direct copier . . . and direct infringement liability when the defendant is a database builder and thus a direct copier ....."). The American Association of University Presses and the Authors Guild argued that Google's plan to scan and centralize 
tent might have been determinative of the primary issue of the suits: whether Google was a direct copier of the content, and thus primarily liable for damages, or whether Google's plan instead constituted fair use. ${ }^{137}$ Indeed, like Napster, Google was likely to lose in light of the centralization of the protected content. ${ }^{138}$ Eventually, however, the parties reached agreements and the suits were settled. ${ }^{139}$

Lessig criticized these settlements, explaining that the settlement agreements erected copyright barriers that exist with respect to every page of copyrighted material, and perhaps even every quote. ${ }^{140}$ These barriers exist because the agreement mandates that the type of book, as well as the type of tables or pictures contained therein, determines whether a book is "free." 141 In light of these barriers, copyright will intrude more frequently into the access of content and, hence, further impede access to all forms of recorded information. ${ }^{142}$ It may also successfully create more criminals in the process. ${ }^{143}$

To comprehend the potential impact of these settlement agreements, one must understand why an entire generation disre-

nearly 18 million books constituted a direct copy of protected content without permission, thus violating copyright law. See id. (alluding to central issue of dispute in case). On the other hand, Google maintained that their plan constituted "fair use" of the content and did not violate copyright law. See id. (noting Google's arguments).

137. See id. (defining pivotal issue in lawsuits).

138. See A\&M Recs., Inc. v. Napster, Inc., 239 F.3d 1004, 1029 (9th Cir. 2001) (showing court's holding in Napster).

139. See Lessig, supra note 88, at 27 (explaining reasons for Google's inclination to settle).

140. See id. ("The deal constructs a world in which control can be exercised at the level of a page, and maybe even a quote."). Lessig explains that the terms of these agreements allow Google to carry out its plan, but makes nearly every use of protected, creative content a regulated event. See id. (noting that Google's agreement created "a world in which every bit, every published word, could be licensed").

141. See id. (describing way in which certain materials are withheld, while others are free to access on Google).

142. See id. (outlining changes to available access of material because of internet capabilities). Nearly every use of protected content would be controlled and regulated if the access to content is determined by analyzing the type of book and the contents therein. See id. (illustrating copyright barriers).

143. See id. at 28 (quoting Michigan Law Professor, Jessica Litman, explaining how complex copyright law has become over the years).

At the turn of the century, U.S. copyright law was technical, inconsistent, and difficult to understand, but it didn't apply to very many people or very many things .... Ninety years later, U.S. copyright law is even more technical, inconsistent and difficult to understand-but more imporId. tantly, it touches everyone and everything. 
gards the way copyright law functions in an online environment or if the generation simply does not understand the law. ${ }^{144}$ Analysing the education of our children is a good starting point in understanding this phenomenon. Jessica Litman, Professor of Law at Wayne State University, illustrates the effect that the internet and poor education can have on compliance with copyright laws by retelling an incident that occurred in her young son's class. ${ }^{145}$ Professor Litman recalls that when her son was in third grade he was assigned a research project on the animal life, plant life, and climate of the alpine tundra. Instead of consulting texts for the necessary research, the teacher explained how to access this information over the internet. ${ }^{146}$ Moreover, "[a]t the end of the school year, this teacher ... presented all of the students with a souvenir: A home-burned CD full of Room A-9's favorite songs" that the teacher downloaded from the Internet. ${ }^{147}$ Professor Litman notes that: 'collecting information on the Internet is 'learning.' Posting information on the net is 'sharing.' Try exactly the same thing with recorded music and it is 'stealing." "148 Children are unlikely to clearly grasp the difference, yet they are already partaking in crime! Moreover, the grey areas of copyright law work to aggravate this unrecognized distinction. ${ }^{149}$

Another problem that leads to copyright law violations is that young file-sharers are prone to peer-pressure, referred to as "pluralistic ignorance" by social psychologists, which arises from ambiguous social situations. ${ }^{150}$ Eventually, these children grow into adults with conflicted perceptions on copyright protection, which has at some point been reinforced by the older generation. The story of Room A-9 is a prime example of a teacher's unawareness of her

144. See Editorial, Court Action Can't Halt Illegal Dowmloading, Daily ILLINI, Nov. 9, 2010, available at http://www.dailyillini.com/opinions/editorials/2010/11/09/ court-action-can-t-halt-illegal-downloading (discussing impact, or lack thereof, of popular illegal downloading website getting shut down by court order). grade).

145. See Litman, supra note 40, at 23 (articulating son's experience in third

146. See id. (explaining increasing use of internet to access material).

147. See id. (describing Professor Litman's son's experience in third grade). Children grow up accessing all types of data and information from the Internet, and this practice causes confusion or apathy as to what material, if accessed, constitutes a copyright law violation. See id.(noting children's confusion regarding what constitutes copyright violations).

148. Id. (demonstrating subtle line between proper and improper Internet content access).

149. See id. (positing that copyright laws are not clear enough to remedy this problem).

150. See Yu, supra note 32, at 757 (detailing prevalence of "pluralistic ignorance" and its causes). 
actions, the lessons of those actions, and the detrimental effects on copyright law. Children, in fact, have more important things to do, and it is ridiculous to expect them to internalize the "nitty gritty" of copyright proprietary laws that adults themselves cannot. ${ }^{151}$

Violations of copyright law have, therefore, become increasingly difficult to regulate; indeed, it is challenging to deter or punish conduct that society no longer seems to consider a crime. ${ }^{152}$ In fact, "the average person does not think there is anything wrong with giving copyrighted work to their friends." 153 This perception is explained by the "cultural difference between the public's perceptions toward analog and Internet material."154

This distinctive treatment of Internet material is evident in the public backlash that surrounded the RIAA's claims against U.S. individuals and serves as a major reason why the movie industry is reluctant to use individual litigation as an avenue for redress against Internet copyright violators. ${ }^{155}$ When the Napster case was unfolding, consumers developed several unhealthy attitudes toward the music industry, including: the perceptions that capitalism ruined music, that artists are more than sufficiently wealthy, and that music labels must be tamed. ${ }^{156}$ With the demise of Napster and the piracy wars, however, these perceptions have declined. ${ }^{157}$ Fortunately, there also seems to be a shift towards realism in copyright, which involves an erosion of the conception that copyright holders can and should control every instance of copying. ${ }^{158}$

151. See id. (describing heart of issue that perpetuates copyright infringement, as law stands today).

152. See id. (discussing extent of copyright law violations in the educational setting). Violations are so widespread that attempting to punish the violations would be arbitrary, under-inclusive, and would fail to resolve the issues. See id. at 758-60 (positing possible remedies).

153. Elizabeth Gard, Conversations with Renowned Professors on the Future of Copyright, 12 Tul. J. Tech. \& INtell. Prop. 35, 38 (2009).

154. Id. at 37.

155. See Matthew Sag, Piracy: Twelve Year-Olds, Grandmothers, and Other Good Targets for the Recording Industry's File Sharing Litigation, 4 Nw. J. TECH. \& INTELL. Prop. 133, 133 (2006) ("The recording industry has been lambasted for both the conception and the execution of its end user litigation strategy with commentators warning that such "strong-arm tactics" will ultimately alienate the industry's customers and political allies.").

156. See Kovacs, supra note 1, at 766 (describing libertarian attitudes of Napster users).

157. See id. at 768 ("Once consumers become accustomed to obtaining something for free, they resist paying for it. . . If the perception of music as a free good becomes pervasive, it may be difficult to reverse.")

158. See Gard, supra note 153, at 38 ("Zimmerman also believes that there is a move toward realism in copyright where the notion that copyright owners could and should control every instance of copying is eroding."). 
It is also prudent to question the psychological effect of having laws in place that society views, in hushed tones, as worth circumventing. This is because copyright laws, as currently envisioned, have failed to effectively act as a deterrent. ${ }^{159}$ The larger question, perhaps, is whether such perceptions and trends, especially among the younger generation, could increasingly create an impression that it is okay to disregard other laws in similar fashion as well. That can easily lead to the dilution of the logic behind deterrence, particularly in an online environment.

The rise of political parties that advocate for piracy shows the resilience and unstoppable movement towards a change in understanding copyright. A case in point is the Swedish pirate party, which has a seat in the European Parliament. ${ }^{160}$ Notably, this shows a shift in norms. Therefore, not surprisingly, another Pirate Party has been formed in Britain as well. ${ }^{161}$ The establishment of these Pirate Parties across countries reinforces the position that views on copyright are changing and maturing substantially from those held during the Napster period.

The United States, however, continues to apply pressure for the implementation of a "three-strikes-and-you're-out rule" for the Internet. ${ }^{162}$ This would mean that the infringing individual would have his or her Internet connection taken away. ${ }^{163}$ Europeans have been particularly cautious about such an approach. ${ }^{164}$ It is important to remember that the bulk of such highly technology savvy individuals are often students, at times utilizing university facilities.

159. For a discussion on the magnitude of copyright infringement and societal views of infringement, see supra note 152-154 and accompanying text.

160. See Jerome Socolovsky, In Sweden, 'Pirates' Make the Web a Political Cause, NPR (Sept. 14, 2009), http://www.npr.org/templates/story/story.php?storyId=112 767746 (noting that Swedish Pirate Party has seat in the European parliament).

161. See Will Smale, Election: Can Pirate Party UK Emulate Sweden Success?, BBC News (Apr. 27, 2010), available at http://news.bbc.co.uk/2/hi/uk_news/politics/ election_2010/8644834.stm ("Launched less than a year ago, Pirate Party UK are fielding nine candidates in the general election.").

162. See Gard, supra note 153, at 57 ("Earlier this week, I spent a morning with a representative from a European government who was fairly distressed about the pressure that his and other countries have received from the United States urging implementation of a 'three-strikes-and-you're-out' rule for the Internet.").

163. See id. (discussing European view of "three-strikes-and-you're-out rule").

164. See id. at 37, 57. (discussing Professor Zimmerman's elaboration on three-strikes-and-you're-out view). Professor Zimmerman elaborated on the view of a representative from the European government by stating, "even if he was to think that what those individuals are doing is not ideal, they are still not criminals and should not be treated as such by taking away their Internet connections." Id at 37. 
Perhaps these developments explain the rise of pirate political parties in Europe.

In 1994, LaMacchia, an MIT student prior to the Napster debacle, set up a software website. ${ }^{165}$ On the website, he allowed anyone to make available software of any kind without charging anyone. ${ }^{166}$ The government attempted to criminally prosecute him, utilizing several statutes, including wire fraud. ${ }^{167}$ Ironically, that was before the DMCA was enacted, and today, he might be considered an Internet Service Provider (ISP), lending credence to the ever-changing attitudes that arise with technological changes. ${ }^{168}$

\section{Conclusion}

It is imperative to acknowledge that society is currently at an exceptionally rudimentary point with regard to learning how to distribute Internet content. ${ }^{169}$ Clearly, we cannot possibly know what will definitively work, and certainly cannot know what will work best. ${ }^{170}$ Furthermore, copyright laws, as currently envisioned today, are still open to interpretation and subject to amendment. ${ }^{171}$ Edu-

165. See id. ("LaMacchia, who may have started us down this road even before Napster.").

166. See id. ("He set up a Web site that allowed anyone to make available software of any kind, but he did not charge for it and made no money on the Web site.").

167. See id. at 57 ("When the government tried to prosecute him criminally, they had to resort to wire fraud and other statutes.").

168. See id. at 58 (" $[\mathrm{W}]$ e no longer think about someone playing a role similar to LaMacchia's as an entity, . . . that we would necessarily be going after, because we now view hosting as an activity that deserves significant protection."). Now, to find an ISP liable, copyright owners are given the burden of monitoring for infringing material on an ISP, and are ordinarily required to give an ISP host notice of the infringing material. See id. (discussing treatment of ISPs today).

169. See Zimmerman, supra note 107, at 1394 (discussing contention with newness of Internet and its effect on laws that never took Internet use into consideration).

170. See id. ("The point I am trying to make is that we are at such an early stage in learning how to use the Internet to distribute content that we cannot possibly know what will work, and certainly cannot know what will work best.").

171. See Michael Katz, Recycling Copyright: Survival E Growth in the Remix Age, 13 INTEll. Prop. L. Bull. 21, 52 (2009).

A better understanding of the goals of copyright law, paired with the simple insight that the key driver behind digital technology is the ability to easily cope and distribute, will allow those tasked with amending copyright law to properly frame the issues in copyright terms without needing Id. to understand the details of every new technological development. 
cation and inculcation of values must be utilized in tandem, even as the understanding of the Internet and copyright evolves. ${ }^{172}$

Nevertheless, we are currently producing a global generation of copyright criminals en masse. ${ }^{173}$ This is a trend that must be somewhat curtailed. Re-conceptualizing copyright law from the point of morality to punishment is an imperative starting point. In the midst of these reforms, one must remember the fundamental tenets of punishment, such as deterrence, retribution and rehabilitation, to ensure that intellectual property cyber anarchy is not seen to be the ultimate solution.

172. See id. ("In turn improved awareness on the part of constituents will allow representatives to devote time and resources to the issue and promote discourse and education regarding the proper role of copyright law.").

173. For a discussion on the frequency of copyright infringement in the educational setting, see infra note 152 and accompanying text. 
Jeffrey S. Moorad Sports Law Journal, Vol. 18, Iss. 2 [2011], Art. 6 